\title{
molecules
}

ISSN 1420-3049

www.mdpi.com/journal/molecules

Article

\section{Additional Minor Diterpene Glycosides from Stevia rebaudiana Bertoni}

\section{Indra Prakash * and Venkata Sai Prakash Chaturvedula ${ }^{\dagger}$}

Organic Chemistry Department, The Coca-Cola Company, Global Research and Development, One Coca-Cola Plaza, Atlanta, GA 30313, USA

$\dagger$ Current address: Natural Ingredient Development, Blue California, 30111 Tomas, Rancho Santa Margarita, CA 92688, USA; E-Mail: saipc@bluecal-ingredients.com

* Author to whom correspondence should be addressed; E-Mail: iprakash@coca-cola.com;

Tel.: +1-404-676-3007; Fax: +1-404-598-3007.

Received: 24 September 2013; in revised form: 26 October 2013 / Accepted: 28 October 2013 / Published: 31 October 2013

\begin{abstract}
Two additional novel minor diterpene glycosides were isolated from the commercial extract of the leaves of Stevia rebaudiana Bertoni. The structures of the new compounds were identified as $13-\{\beta$-D-glucopyranosyl- $(1 \rightarrow 2)-O$-[ $\beta$-D-glucopyranosyl$(1 \rightarrow 3)-\beta$-D-glucopyranosyl-oxy $\}$ ent-kaur-16-en-19-oic acid $\{\beta$-D-xylopyranosyl- $(1 \rightarrow 2)$ $O$-[ $\beta$-D-glucopyranosyl- $(1 \rightarrow 3)]-O$ - $\beta$-D-glucupyranosyl-ester $\} \quad(\mathbf{1})$, and 13-\{ $\beta$-D-6-deoxyglucopyranosyl- $(1 \rightarrow 2)-O$-[ $\beta$-D-glucopyranosyl- $(1 \rightarrow 3)-\beta$-D-glucopyranosyl-oxy $\}$ ent-kaur16 -en-19-oic acid $\{\beta$-D-glucopyranosyl- $(1 \rightarrow 2)-O$-[ $\beta$-D-glucopyranosyl- $(1 \rightarrow 3)-\beta$-D-glucopyranosyl-ester $\}$ (2), on the basis of extensive $1 \mathrm{D}\left({ }^{1} \mathrm{H}\right.$ - and $\left.{ }^{13} \mathrm{C}-\right)$ 2D NMR (COSY, HSQC and $\mathrm{HMBC}$ ) and MS spectroscopic data as well as chemical studies.
\end{abstract}

Keywords: Stevia rebaudiana; Compositae; Asteraceae; diterpenoid glycosides; spectral data; chemical studies; structure characterization

\section{Introduction}

The major constituents isolated from the leaves of a perennial shrub Stevia rebaudiana Bertoni (family: Asteraceae) are the potently sweet diterpenoid glycosides stevioside and rebaudioside A. Extracts of the leaves of $S$. rebaudiana native to Brazil and Paraguay have been used for centuries 
to sweeten food and beverages in Japan, South America and China. Due to the increase in demand for the major constituents in the leaves of $S$. rebaudiana which are the potently sweet diterpenoid glycosides stevioside, rebaudiosides A and D, and dulcoside A, it is now grown commercially in a number of countries, particularly in China, Japan, Taiwan, Korea, Thailand and Indonesia [1,2]. The compounds isolated from $S$. rebaudiana known as stevia sweeteners are the glycosides of the diterpene steviol, ent-13-hydroxykaur-16-en-19-oic acid [3].

In our continuing research to discover novel natural sweeteners, we have isolated several new steviol glycosides from the commercial extracts of the leaves of $S$. rebaudiana [4-7]. Apart from isolation and structural characterization of novel compounds from $S$. rebaudiana, and their possible utilization as natural sweeteners or sweetness enhancers, we have also studied the stability of many steviol glycosides in various systems of interest and characterized their degradation products using a number of spectroscopic methods [8]. We are also engaged in the synthesis of selected steviol diterpene glycosides using naturally occurring starting materials [9-11].

\section{Results and Discussion}

Purification of the commercial extract of rebaudioside $\mathrm{M}$ (also known as rebaudioside $\mathrm{X}$ ) obtained from the leaves of $S$. rebaudiana from Lot No: PT01021 of Pure Circle, Malaysia resulted in the isolation of the two new diterpenoid glycosides $13-\{\beta$-D-glucopyranosyl- $(1 \rightarrow 2)-O$-[ $\beta$-D-glucopyranosyl$(1 \rightarrow 3)-\beta$-D-glucopyranosyl-oxy $\}$ ent-kaur-16-en-19-oic acid $\{\beta$-D-xylopyranosyl- $(1 \rightarrow 2)-O$-[ $\beta$-D-glucopyranosyl- $(1 \rightarrow 3)]-O-\beta$-D-glucupyranosyl-ester $\}(\mathbf{1})$, and 13- $\{\beta$-D-6-deoxy-glucopyranosyl- $(1 \rightarrow 2)-O$-[ $[\beta$-Dglucopyranosyl-( $1 \rightarrow 3)-\beta$-D-glucopyranosyl-oxy\} ent-kaur-16-en-19-oic acid $\{\beta$-D-glucopyranosyl-( $1 \rightarrow 2)$ $O$-[ $\beta$-D-glucopyranosyl-( $1 \rightarrow 3)$ - $\beta$-D-glucopyranosyl-ester $\}$ (2) (Figure 1).

Figure 1. Structures of 1, 2 and steviol (3).

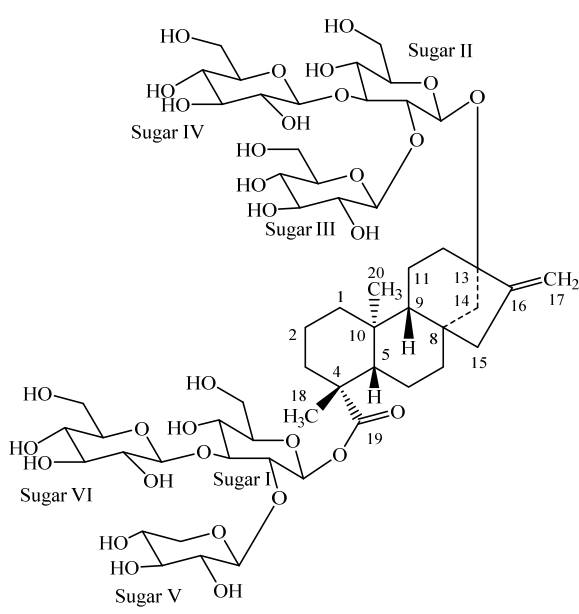

1

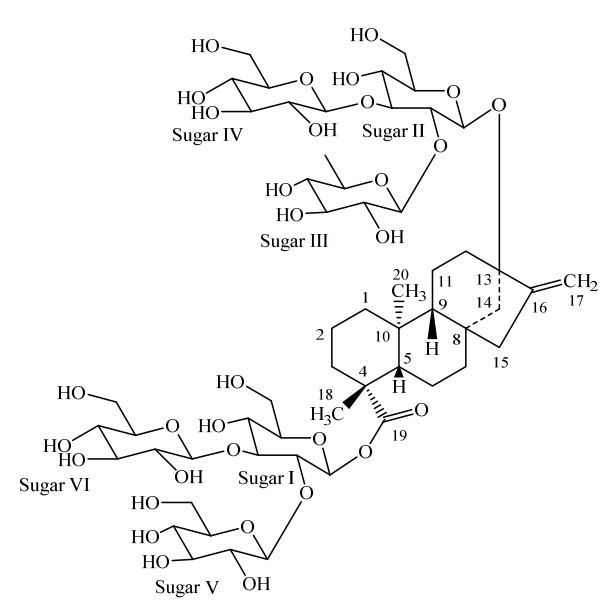

2

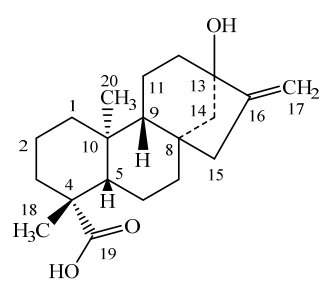


Compound 1 was obtained as a white powder and its molecular formula was deduced as $\mathrm{C}_{55} \mathrm{H}_{88} \mathrm{O}_{32}$ from its HRESI mass spectrum in the positive mode which showed a $(\mathrm{M}+\mathrm{H})^{+}$ion at $\mathrm{m} / \mathrm{z} 1261.5353$; this was supported by the ${ }^{13} \mathrm{C}-\mathrm{NMR}$ spectral data. The ${ }^{1} \mathrm{H}-\mathrm{NMR}$ spectrum of $\mathbf{1}$ showed the presence of two methyl signals resonating at $\delta 1.29$ and 1.36 as singlets, two olefinic proton singlets at $\delta 4.89$ and 5.69 corresponding to an exocyclic double bond, nine methylene and two methine protons between $\delta$ 0.75-2.70, characteristic for the ent-kaurane diterpenoids isolated earlier from the genus Stevia [6-9]. The basic skeleton of ent-kaurane diterpenoids was supported by the key COSY: H-1/H-2; H-2/H-3; H-5/H-6; H-6/H-7; H-9/H-11; H-11/H-12, and HMBC correlations: H-1/C-2, C-10; H-3/C-2, C-4, C-5, C-18, C-19; H-5/C-4, C-6, C-10, C-18, C-19, C-20; H-9/C-8, C-10, C-11; H-14/C-8, C-9, C-13, C-15, $\mathrm{C}-16$ and $\mathrm{H}-17 / \mathrm{C}-13, \mathrm{C}-15, \mathrm{C}-16$ ) correlations [4-11]. The presence of six sugar units in its structure was evident by the presence of the anomeric protons resonating at $\delta 5.33,5.45,5.46,5.48,5.62$, and 6.38 in its ${ }^{1} \mathrm{H}-\mathrm{NMR}$ spectrum. The presence of these six sugar units was further supported by the MS/MS spectrum of 1 in the positive ESI mode that showed fragment ions at $m / z 1129,967,805,643$, 481 and 319; suggesting the presence of a pentose and five hexose moieties in its structure. Acid hydrolysis of 1 with $5 \% \mathrm{H}_{2} \mathrm{SO}_{4}$ afforded the sugars D-glucose and D-xylose, which were identified by direct comparison with authentic samples by TLC [12-14]. The anomeric proton observed at $\delta 6.38$ showed an HMBC correlation to $\mathrm{C}-19$ which indicated that it corresponds to the anomeric proton of Sugar I. Similarly, the anomeric proton observed at $\delta 5.45$ showed an HMBC correlation to C-13 allowing it to be assigned as the anomeric proton of Sugar II. The sequence in sugar units and the assignments for C-2 through C-6 of Glc $\mathrm{V}_{\mathrm{V}}$ and Glc $\mathrm{VI}_{\mathrm{I}}$ were made using the ${ }^{1} \mathrm{H}-\mathrm{NMR}, \mathrm{COSY}$ and HSQC data. Further, the identification of sugars present in $\mathbf{1}$ and their configurations were achieved by preparing their thiocarbamoyl-thiazolidine carboxylate derivatives with L-cysteine methyl ester and $O$-tolyl isothiocyanate, and comparison of their retention times with the standard sugars as described in the literature; suggesting the sugar moieties present as $\beta$-D-glucopyranosyl and $\beta$-D-xylopyranosyl units [15]. Enzymatic hydrolysis of 1 furnished an aglycone which was identified as steviol (3) by comparison of ${ }^{1} \mathrm{H}-\mathrm{NMR}$ and co-TLC with a standard [16]. The large coupling constants observed for the six anomeric protons of the sugar moieties at $\delta 5.33(\mathrm{~d}, J=8.1 \mathrm{~Hz}), 5.45(\mathrm{~d}, J=7.8 \mathrm{~Hz}), 5.46(\mathrm{~d}$, $J=7.5 \mathrm{~Hz}), 5.48(\mathrm{~d}, J=7.9 \mathrm{~Hz}), 5.62(\mathrm{~d}, J=7.8 \mathrm{~Hz})$, and $6.38(\mathrm{~d}, J=8.4 \mathrm{~Hz})$, suggested their $\beta$-orientation, as reported for steviol glycosides [4-11]. The ${ }^{1} \mathrm{H}$ - and ${ }^{13} \mathrm{C}-\mathrm{NMR}$ values for all the proton and carbons were assigned on the basis of 2D NMR spectral data (COSY, HSQC and HMBC) and are given in Table 1.

From the above NMR spectral data and hydrolysis studies, it was inferred that there are five $\beta$-D-glucopyranosyl units and a $\beta$-D-xylopyranosyl unit in the structure of $\mathbf{1}$ connected to the aglycone steviol. Comparison of the ${ }^{1} \mathrm{H}$ - and ${ }^{13} \mathrm{C}-\mathrm{NMR}$ values of 1 with rebaudioside $\mathrm{D}[4,17]$ suggested the presence of a steviol aglycone moiety with a 2,3-branched $\beta$-D-glucotriosyl substituent and another $\beta$-D-glucosyl moiety in the form of an ester at C-19, leaving the assignment of the additional $\beta$-D-glucosyl and $\beta$-D-xylosyl moieties. The downfield shift for both the ${ }^{1} \mathrm{H}$ and ${ }^{13} \mathrm{C}$ chemical shifts at C-2' and C-3' of sugar I (C-19 position) suggested that the additional $\beta$-D-xylosyl and $\beta$-D-glucosyl moieties are attached at thse positions respectively. This was confirmed by the key HMBC correlations as shown in Figure 2. Based on the results from chemical and spectral studies, 1 was assigned as 13- $\{\beta$-Dglucopyranosyl- $(1 \rightarrow 2)-O$-[ $\beta$-D-glucopyranosyl-( $1 \rightarrow 3)$ - $\beta$-D-glucopyranosyl-oxy $\} \quad$ ent-kaur-16-en-19-oic acid $\{\beta$-D-xylopyranosyl-( $1 \rightarrow 2)-O$-[ $\beta$-D-glucopyranosyl- $(1 \rightarrow 3)]-O-\beta$-D-glucupyranosyl-ester $\}$. 
Table 1. ${ }^{1} \mathrm{H}$ - and ${ }^{13} \mathrm{C}-\mathrm{NMR}$ chemical shift values for $\mathbf{1}-\mathbf{2}$ isolated from Stevia rebaudiana Bertoni recorded in $\mathrm{d} 5$-pyridine $\left(\mathrm{C}_{5} \mathrm{D}_{5} \mathrm{~N}\right)^{\mathrm{a}-\mathrm{c}}$.

\begin{tabular}{|c|c|c|c|c|}
\hline \multirow{2}{*}{ Position } & \multicolumn{2}{|l|}{1} & \multicolumn{2}{|l|}{2} \\
\hline & ${ }^{1}$ H-NMR & ${ }^{13} \mathrm{C}-\mathrm{NMR}$ & ${ }^{1}$ H-NMR & ${ }^{13} \mathrm{C}-\mathrm{NMR}$ \\
\hline 1 & $0.75 \mathrm{brt}(13.2), 1.76 \mathrm{~m}$ & 40.0 & $0.77 \mathrm{brt}(12.3), 1.79 \mathrm{~m}$ & 39.9 \\
\hline 2 & $1.35 \mathrm{~m}, 2.23 \mathrm{~m}$ & 19.4 & $1.37 \mathrm{~m}, 2.28 \mathrm{~m}$ & 19.3 \\
\hline 3 & $1.01 \mathrm{~m}, 2.29 \mathrm{~m}$ & 38.0 & $1.02 \mathrm{~m}, 2.29 \mathrm{~m}$ & 38.1 \\
\hline 4 & - & 43.9 & - & 44.0 \\
\hline 5 & $1.02 \mathrm{brd}(13.0)$ & 57.0 & 1.06 br d (12.9) & 57.0 \\
\hline 6 & $2.07 \mathrm{~m}, 2.42 \mathrm{q}(13.5)$ & 23.1 & $2.24 \mathrm{~m}, 2.41 \mathrm{~m}$ & 23.2 \\
\hline 7 & $1.37 \mathrm{~m}, 1.73 \mathrm{~m}$ & 42.2 & $1.42 \mathrm{~m}, 1.81 \mathrm{~m}$ & 42.3 \\
\hline 8 & - & 39.2 & - & 39.7 \\
\hline 9 & 0.90 br d (8.1) & 54.0 & 0.92 br d (7.7) & 54.0 \\
\hline 10 & - & 41.3 & - & 41.4 \\
\hline 11 & $1.65 \mathrm{~m}, 1.75 \mathrm{~m}$ & 19.9 & $1.67 \mathrm{~m}, 1.76 \mathrm{~m}$ & 19.8 \\
\hline 12 & $1.86 \mathrm{~m}, 2.70 \mathrm{~m}$ & 38.2 & $1.81 \mathrm{~m}, 2.74 \mathrm{~m}$ & 38.1 \\
\hline 13 & - & 87.5 & - & 87.4 \\
\hline 14 & $2.01 \mathrm{~m}, 2.72 \mathrm{~m}$ & 42.9 & $2.01 \mathrm{~m}, 2.75 \mathrm{~m}$ & 42.9 \\
\hline 15 & $1.88 \mathrm{~d}(17.0), 2.04 \mathrm{~m}$ & 46.3 & $1.88 \mathrm{~m}, 2.05 \mathrm{~m}$ & 46.1 \\
\hline 16 & - & 153.9 & - & 153.7 \\
\hline 17 & $4.89 \mathrm{~s}, 5.69 \mathrm{~s}$ & 104.6 & $4.89 \mathrm{~s}, 5.72 \mathrm{~s}$ & 104.5 \\
\hline 18 & $1.29 \mathrm{~s}$ & 27.9 & $1.32 \mathrm{~s}$ & 27.9 \\
\hline 19 & - & 176.7 & - & 177.0 \\
\hline 20 & $1.36 \mathrm{~s}$ & 16.4 & $1.38 \mathrm{~s}$ & 16.6 \\
\hline $1^{\prime}$ & $6.38 \mathrm{~d}(8.4)$ & 94.4 & $6.41 \mathrm{~d}(8.2)$ & 94.5 \\
\hline $2^{\prime}$ & $4.38 \mathrm{~m}$ & 77.1 & $4.52 \mathrm{t}(8.7)$ & 76.5 \\
\hline $3^{\prime}$ & $5.04 \mathrm{~m}$ & 88.2 & $5.14 \mathrm{t}(8.7)$ & 88.2 \\
\hline $4^{\prime}$ & $4.24 \mathrm{~m}$ & 69.8 & $4.20 \mathrm{~m}$ & 69.7 \\
\hline $5^{\prime}$ & $4.14 \mathrm{~m}$ & 78.3 & $4.14 \mathrm{~m}$ & 78.0 \\
\hline $6^{\prime}$ & $\begin{array}{l}4.20 \mathrm{~m} \\
4.33 \mathrm{~m}\end{array}$ & 61.7 & $4.20 \mathrm{~m}, 4.30 \mathrm{~m}$ & 61.7 \\
\hline $1 "$ & $5.45 \mathrm{~d}(7.8)$ & 96.0 & $5.49 \mathrm{~d}(7.9)$ & 95.9 \\
\hline $2^{\prime \prime}$ & $4.13 \mathrm{~m}$ & 81.0 & $4.08 \mathrm{~m}$ & 81.1 \\
\hline $3 "$ & $4.98 \mathrm{t}(9.1)$ & 87.6 & $5.01 \mathrm{~m}$ & 87.7 \\
\hline $4 "$ & $4.08 \mathrm{t}(9.1)$ & 70.1 & $4.09 \mathrm{~m}$ & 70.3 \\
\hline $5^{\prime \prime}$ & $3.95 \mathrm{~m}$ & 77.4 & $3.96 \mathrm{~m}$ & 77.4 \\
\hline $6 "$ & $4.21 \mathrm{~m}, 4.35 \mathrm{~m}$ & 62.4 & $4.20 \mathrm{~m}, 4.32 \mathrm{~m}$ & 62.2 \\
\hline $1 " '$ & $5.48 \mathrm{~d}(7.9)$ & 104.5 & $5.39 \mathrm{~d}(8.0)$ & 104.3 \\
\hline $2^{\prime \prime \prime}$ & $4.16 \mathrm{~m}$ & 75.3 & $4.14 \mathrm{~m}$ & 75.5 \\
\hline $3^{\prime \prime \prime}$ & $4.13 \mathrm{~m}$ & 78.2 & $4.04 \mathrm{~m}$ & 78.1 \\
\hline $4 " '$ & $3.99 \mathrm{~m}$ & 72.9 & $3.69 \mathrm{t}(8.9)$ & 76.7 \\
\hline $5^{\prime \prime \prime}$ & $3.75 \operatorname{ddd}(3.1,6.5,9.7)$ & 77.3 & $3.47 \mathrm{dq}(6.0,8.9)$ & 72.4 \\
\hline $6^{\prime \prime \prime}$ & $4.28 \mathrm{~m}, 4.51 \mathrm{dd}(1.1,11.6)$ & 63.6 & $1.63 \mathrm{~d}(6.1)$ & 18.3 \\
\hline $1^{\prime \prime \prime}$ & $5.46 \mathrm{~d}(7.5)$ & 103.8 & $5.48 \mathrm{~d}(7.9)$ & 103.5 \\
\hline $2^{\prime \prime \prime \prime}$ & $3.98 \mathrm{~m}$ & 75.2 & $4.00 \mathrm{~m}$ & 75.2 \\
\hline
\end{tabular}


Table 1. Cont.

\begin{tabular}{|c|c|c|c|c|}
\hline \multirow{2}{*}{ Position } & \multicolumn{2}{|l|}{1} & \multicolumn{2}{|l|}{2} \\
\hline & ${ }^{1} \mathrm{H}-\mathrm{NMR}$ & ${ }^{13} \mathrm{C}-\mathrm{NMR}$ & ${ }^{1} \mathrm{H}-\mathrm{NMR}$ & ${ }^{13} \mathrm{C}-\mathrm{NMR}$ \\
\hline $3^{\prime \prime \prime \prime}$ & $4.47 \mathrm{t}(8.6)$ & 77.6 & $4.55 \mathrm{t}(9.2)$ & 77.4 \\
\hline $4^{\prime \prime \prime \prime}$ & $4.14 \mathrm{~m}$ & 70.9 & $4.18 \mathrm{~m}$ & 71.0 \\
\hline $5^{\prime \prime \prime \prime}$ & $3.99 \mathrm{~m}$ & 77.7 & $4.01 \mathrm{~m}$ & 77.6 \\
\hline $6^{\prime \prime \prime \prime}$ & $4.20 \mathrm{~m}, 4.33 \mathrm{~m}$ & 61.7 & $4.20 \mathrm{~m}, 4.30 \mathrm{~m}$ & 61.7 \\
\hline $1 " '+"$ & $5.62 \mathrm{~d}(7.8)$ & 104.7 & $5.81 \mathrm{~d}(7.5)$ & 103.9 \\
\hline $2^{\prime \prime \prime \prime \prime}$ & $4.17 \mathrm{~m}$ & 75.2 & $4.25 \mathrm{~m}$ & 75.0 \\
\hline 3"'"' & $4.12 \mathrm{~m}$ & 78.3 & $4.18 \mathrm{~m}$ & 78.0 \\
\hline 4"'"' & $4.32 \mathrm{~m}$ & 71.3 & $4.10 \mathrm{~m}$ & 73.3 \\
\hline $5^{\prime \prime \prime \prime}$ & $3.54 \mathrm{t}(11.0), 4.32 \mathrm{~m}$ & 66.6 & $3.90 \operatorname{ddd}(3.3,6.8,9.3)$ & 77.4 \\
\hline $6^{\prime \prime " '}$ & - & - & $4.32 \mathrm{~m}, 4.66 \mathrm{~d}(11.3)$ & 63.6 \\
\hline $1 "$ "'"' & $5.33 \mathrm{~d}(8.1)$ & 103.9 & $5.30 \mathrm{~d}(8.0)$ & 103.9 \\
\hline $2^{\prime \prime \prime \prime \prime \prime}$ & $3.97 \mathrm{~m}$ & 75.2 & $3.95 \mathrm{~m}$ & 75.1 \\
\hline $3^{\prime \prime \prime \prime \prime \prime}$ & $4.38 \mathrm{~m}$ & 77.5 & $4.33 \mathrm{~m}$ & 77.6 \\
\hline 4"'"'" & $4.11 \mathrm{~m}$ & 70.9 & $4.09 \mathrm{~m}$ & 70.6 \\
\hline $5^{\prime \prime \prime " ' ~}$ & $3.87 \mathrm{~m}$ & 77.8 & $3.82 \mathrm{~m}$ & 77.7 \\
\hline 6"'"'"' & $4.10 \mathrm{~m}, 4.31 \mathrm{~m}$ & 61.8 & $4.10 \mathrm{~m}, 4.32 \mathrm{~m}$ & 61.7 \\
\hline
\end{tabular}

${ }^{\mathrm{a}}$ assignments made on the basis of COSY, HSQC and HMBC correlations; ${ }^{\mathrm{b}}$ Chemical shift values are in $\delta$ (ppm); ${ }^{\mathrm{c}}$ Coupling constants are in $\mathrm{Hz}$.

Figure 2. Key COSY and HMBC correlations of $\mathbf{1 .}$

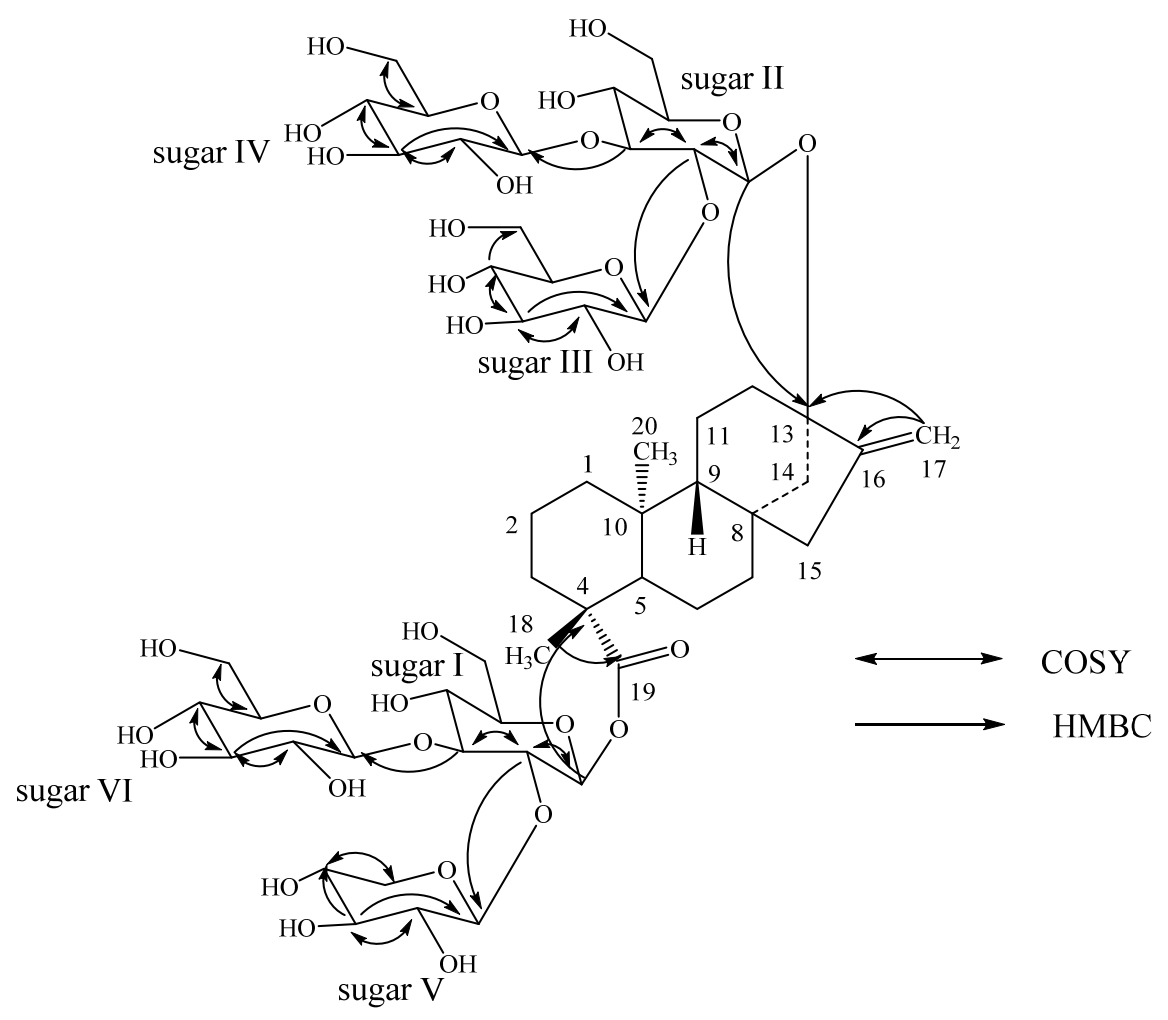

The molecular formula of compound 2 was determined to be $\mathrm{C}_{56} \mathrm{H}_{90} \mathrm{O}_{32}$ by the $[\mathrm{M}+\mathrm{H}]^{+}$ion at $\mathrm{m} / \mathrm{z} 1,275.5485$ in the positive ESI mass spectrum which was further supported by the ${ }^{13} \mathrm{C}$-NMR 
spectral data. The ${ }^{1} \mathrm{H}-\mathrm{NMR}$ spectrum of 2 also showed the presence of two methyl singlets, nine methylene and two methine protons as in 1. The positive ESI MS/MS spectrum of 2 showed the fragment ions at $\mathrm{m} / \mathrm{z} 1,129,967,805,643,481$, and 319 corresponding to the successive loss of a deoxyhexose and five hexose units from its $[\mathrm{M}+\mathrm{H}]^{+}$ion, which was supported by the six anomeric protons observed at $\delta 5.30,5.39,5.48,5.49,5.81,6.41$ in its ${ }^{1} \mathrm{H}-\mathrm{NMR}$ spectral data. Acid hydrolysis of 2 performed using the same procedure described as in $\mathbf{1}$ afforded D-glucose and D-deoxyglucose confirming the presence of a D-deoxypyranosyl and five D-glucopyranosyl units in its molecular structure. The two sugars present in $\mathbf{2}$ were identified as $\beta$-D-glucopyranosyl and $\beta$-D-6-deoxyglucopyranosyl units by preparing their thiocarbamoyl-thiazolidine carboxylate derivatives with L-cysteine methyl ester and $O$-tolyl isothiocyanate, as in 1. The large coupling constants observed for the six anomeric protons suggested their $\beta$-orientation, as reported for steviol glycosides such as in the case of $\mathbf{1}$.

Enzymatic hydrolysis of $\mathbf{2}$ furnished a compound which was found identical to steviol (3) as in 1. A close comparison of the ${ }^{1} \mathrm{H}$ - and ${ }^{13} \mathrm{C}$-NMR values of $\mathbf{2}$ with $\mathbf{1}$ and rebaudioside $\mathrm{D}$ suggested the presence of three glucose units attached as a 2,3-branched $\beta$-D-glucotriosyl substituent at C-19 carboxylic acid with another $\beta$-D-glucosyl moiety at C-13 hydroxyl leaving the assignment of the additional $\beta$-D-glucosyl and a $\beta$-D-deoxyglucosyl moieties. From the key COSY and HMBC correlations shown in Figure 3, it was concluded that $\beta$-D-deoxyglucosyl and $\beta$-D-glucosyl units have been connected at $\mathrm{C}-2$ and $\mathrm{C}-3$ positions respectively to the $\beta$-D-glucosyl moiety at $\mathrm{C}-13$ position. Thus, the structure of the novel compound 2 has been deduced as 13-\{ $\beta$-D-6-deoxy-glucopyranosyl$(1 \rightarrow 2)-O$-[ $\beta$-D-glucopyranosyl-( $1 \rightarrow 3)$ - $\beta$-D-glucopyranosyl-oxy $\} \quad$ ent-kaur-16-en-19-oic acid $\{\beta$-D-glucopyranosyl-( $1 \rightarrow 2)-O$-[ $\beta$-D-glucopyranosyl- $(1 \rightarrow 3)$ - $\beta$-D-glucopyranosyl-ester $\}$.

Figure 3. Key COSY and HMBC correlation of 2.

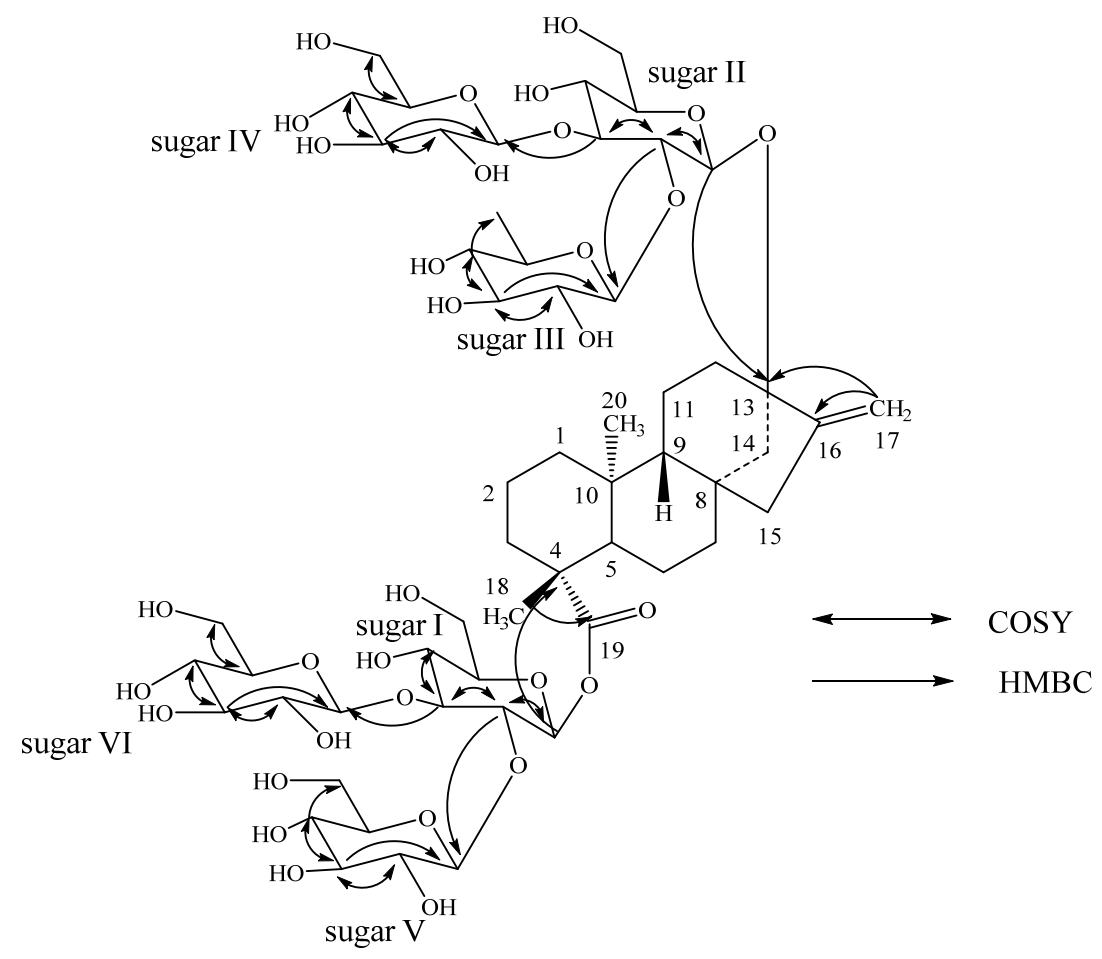




\section{Experimental}

\subsection{General}

NMR spectra were acquired on a Bruker Avance DRX $500 \mathrm{MHz}$ instrument with a $5 \mathrm{~mm}$ inverse detection probe using standard pulse sequences. The spectrum was referenced to the residual solvent signal $\left(\delta_{\mathrm{H}} 8.71, \delta_{\mathrm{C}} 149.9\right.$ for pyridine- $\left.d_{5}\right)$, chemical shifts are given in $\delta(\mathrm{ppm})$, and coupling constants are reported in Hz. High Resolution Mass Spectral (HRMS) and MS/MS fragmentation pattern data were generated in the positive-ion mode using a mass spectrometer (Waters Premier Quadrupole Time-of-Flight) equipped with an electrospray ionization source. Samples were diluted with water: acetonitrile (1:1) containing $0.1 \%$ formic acid and introduced via infusion using the onboard syringe pump.

\subsection{Plant Material}

The commercial rebaudioside M with Lot No: PT01021 was obtained from Pure Circle, Malaysia. A voucher specimen is deposited at The Coca-Cola Company, No. VSPC-2973-6B.

\subsection{Isolation}

Isolation of the pure compounds 1-2 has been carried out using an Agilent 1100 HPLC fractionation of a sample of rebaudioside M (VSPC-2973-6B, $2 \mathrm{~g}$ ). The HPLC method involved using Phenomenex Prodigy Column $\mathrm{C}_{18}(250 \times 10 \mathrm{~mm}, 10 \mu \mathrm{m})$; UV Detection: $210 \mathrm{~nm}$; Mobile Phase A: $\mathrm{H}_{2} \mathrm{O}$ (0.1\% TFA); Mobile Phase B: acetonitrile; Flow Rate: $20.0 \mathrm{~mL} / \mathrm{min}$; Injection volume: 1,400 $\mu \mathrm{L}$. The gradient increased from 75:25 (A:B) to 69:31 (A:B) over $20 \mathrm{~min}$, and remained at 50:50 (A:B) for 5 min. The peaks eluting at $t_{R} 17.18$ and $18.29 \mathrm{~min}$ were collected over several injections and concentration under vacuum furnished $\mathbf{1}(2.4 \mathrm{mg})$ and $\mathbf{2}(1.8 \mathrm{mg})$ respectively (Figure 4$)$.

Figure 4. HPLC Trace of mixture of 1 and 2.

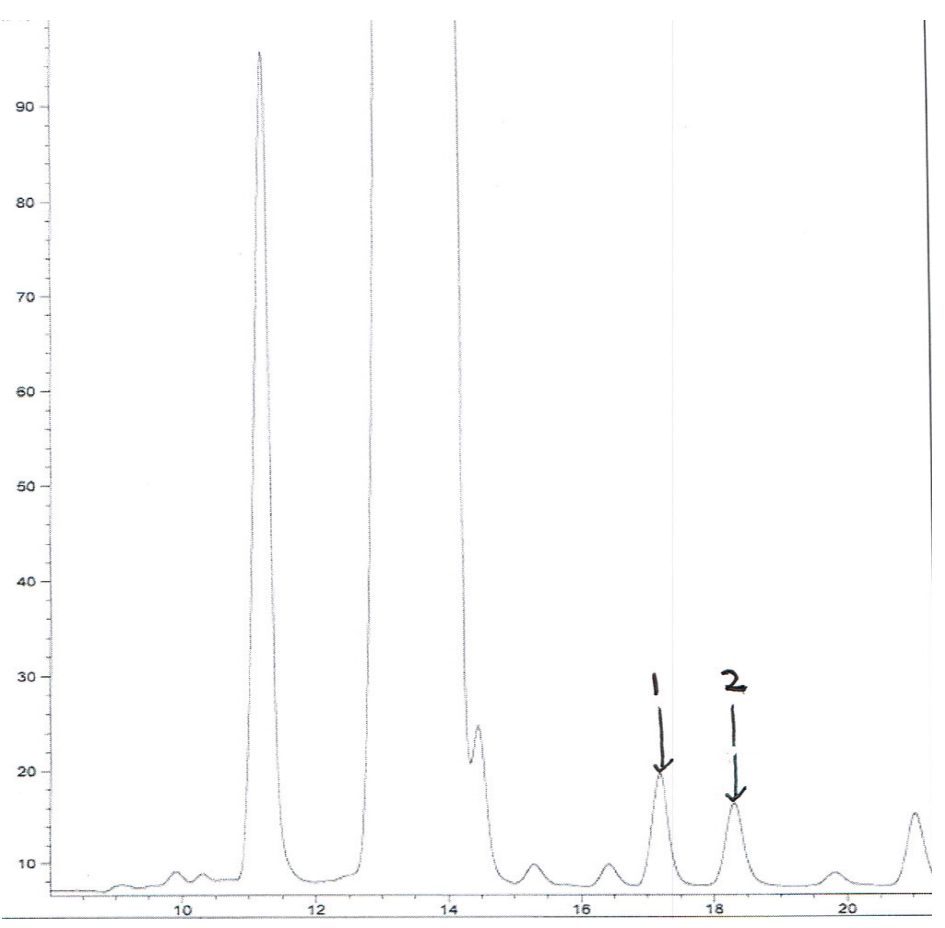


13-\{ $\{$-D-Glucopyranosyl-( $1 \rightarrow 2)-O-[\beta-D$-glucopyranosyl- $(1 \rightarrow 3)-\beta$-D-glucopyranosyl-oxy $\}$ ent-kaur-16-en19 -oic acid $\{\beta$-D-xylopyranosyl-( $(\rightarrow 2)-O$-[ $\beta$-D-glucopyranosyl- $(1 \rightarrow 3)]-O-\beta$-D-glucupyranosyl-ester $\}$ (1); White powder, ${ }^{1} \mathrm{H}-\mathrm{NMR}\left(500 \mathrm{MHz}, \mathrm{C}_{5} \mathrm{D}_{5} \mathrm{~N}, \delta \mathrm{ppm}\right)$ and ${ }^{13} \mathrm{C}-\mathrm{NMR}\left(125 \mathrm{MHz}, \mathrm{C}_{5} \mathrm{D}_{5} \mathrm{~N}, \delta \mathrm{ppm}\right)$ spectroscopic data see Table 1; HRESIMS (M+H) ${ }^{+} m / z 1261.5353$ (calcd. for $\mathrm{C}_{55} \mathrm{H}_{89} \mathrm{O}_{32}$ : 1261.5337).

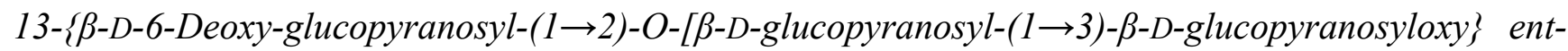
kaur-16-en-19-oic acid $\{\beta$-D-glucopyranosyl- $(1 \rightarrow 2)-O$ - $[\beta$-D-glucopyranosyl- $(1 \rightarrow 3)-\beta$-D-gluco-pyranosylester\} (2); White powder, ${ }^{1} \mathrm{H}-\mathrm{NMR}\left(500 \mathrm{MHz}, \mathrm{C}_{5} \mathrm{D}_{5} \mathrm{~N}, \delta \mathrm{ppm}\right)$ and ${ }^{13} \mathrm{C}-\mathrm{NMR}\left(125 \mathrm{MHz}, \mathrm{C}_{5} \mathrm{D}_{5} \mathrm{~N}\right.$, $\delta$ ppm) spectroscopic data see Table 1; HRESIMS $(\mathrm{M}+\mathrm{H})^{+} m / z 1275.5485$ (calcd. for $\mathrm{C}_{56} \mathrm{H}_{91} \mathrm{O}_{32}$ : 1275.5493).

Acid hydrolysis of $\mathbf{1}$ and $\mathbf{2}$. To a solution of compounds $\mathbf{1}$ and $\mathbf{2}(500 \mu \mathrm{g})$ in $\mathrm{MeOH}(1 \mathrm{~mL})$ was added $5 \% \mathrm{H}_{2} \mathrm{SO}_{4}(0.5 \mathrm{~mL})$ and the mixture was refluxed for $24 \mathrm{~h}$. The resulting reaction mixture was extracted with ethyl acetate (EtOAc, $2 \times 10 \mathrm{~mL}$ ) after neutralization with saturated aqueous sodium carbonate solution yields an aqueous fraction containing sugars. The sugars present in the aqueous phase were identified as D-glucose and D-xylose in 1, and D-glucose and 6-deoxy-D-glucose in 2, by comparing with standard sugars using the TLC systems EtOAc/n-butanol/water $(2: 7: 1)$ and $\mathrm{CH}_{2} \mathrm{Cl}_{2} / \mathrm{MeOH} /$ water (10:6:1) [12-14].

Determination of sugar configuration in $\mathbf{1}$ and 2. Each compound 1-2 (1 mg) was hydrolyzed with $0.5 \mathrm{M} \mathrm{HCl}(2 \mathrm{~mL})$ for $1.5 \mathrm{~h}$. The reaction mixture was cooled to room temperature, passed through an Amberlite IRA400 column and the eluate was lyophilized. The residue was dissolved in pyridine $(1 \mathrm{~mL})$ and heated with L-cysteine methyl ester $\mathrm{HCl}(5 \mathrm{mg})$ at $60{ }^{\circ} \mathrm{C}$ for $1.5 \mathrm{~h}$, and then $O$-tolyl isothiocyanate $(25 \mu \mathrm{L})$ was added to the mixture and heated at $60{ }^{\circ} \mathrm{C}$ for an additional $1.5 \mathrm{~h}$. The reaction mixture was analyzed by HPLC: column Phenomenex Luna $\mathrm{C}_{18}, 150 \times 4.6 \mathrm{~mm}(5 \mu \mathrm{L})$; Mobile phase: $25 \%$ acetonitrile in water with $0.2 \%$ TFA, Flow rate: $1 \mathrm{~mL} / \mathrm{min}$; UV detection at $250 \mathrm{~nm}$. The sugars were identified as D-glucose $\left(t_{R}, 12.34 \mathrm{~min}\right)$ and D-xylose $\left(t_{R}, 14.08\right)$ in $\mathbf{1}$, whereas D-glucose $\left(t_{R}, 12.26 \mathrm{~min}\right)$ 6-deoxy-D-gluose $\left(t_{R}, 11.34 \mathrm{~min}\right)$ in 2 [(authentic samples, D-glucose $\left(t_{R}, 12.64\right)$ and L-glucose $\left(t_{R}, 11.36 \mathrm{~min}\right)$; D-xylose $\left(t_{R}, 14.23\right)$ and L-xylose $\left(t_{R}, 13.06 \mathrm{~min}\right)$; 6-deoxy-Dglucose $\left(t_{R}, 11.04\right)$ and 6-deoxy-L-glucose $\left.\left(t_{R}, 17.68\right)\right]$ [15].

Enzymatic hydrolysis of $\mathbf{1}$ and 2. To a solution of each compound 1-2 (250 $\mu \mathrm{g})$ was added $0.1 \mathrm{M}$ sodium acetate buffer, $\mathrm{pH} 4.5(5 \mathrm{~mL})$ and crude pectinase from Aspergillus niger $(\mathrm{P} 2736,50 \mu \mathrm{L}$, Sigma-Aldrich, St. Louis, MO, USA). The mixture was stirred at $50{ }^{\circ} \mathrm{C}$ for $120 \mathrm{~h}$. The product precipitated out during the reaction and was filtered and then crystallized from methanol $(\mathrm{MeOH})$. The resulting product was identical to ent-13-hydroxykaur-16-en-19-oic acid (steviol, 3 ) by comparison of their ${ }^{1}$ H-NMR spectral data and co-TLC [16].

\section{Conclusions}

Two novel diterpenoid glycosides 1-2 were isolated from a commercial sample of rebaudioside $\mathrm{M}$ of the leaves of $S$. rebaudiana Bertoni obtained from Pure Circle, Malaysia. The structure of the new compounds were identified as $13-\{\beta$-D-glucopyranosyl- $(1 \rightarrow 2)-O-[\beta$-D-glucopyranosyl- $(1 \rightarrow 3)-\beta$-Dglucopyranosyl-oxy $\}$ ent-kaur-16-en-19-oic acid $\{\beta$-D-xylopyranosyl- $(1 \rightarrow 2)-O$-[ $\beta$-D-glucopyranosyl- 
$(1 \rightarrow 3)]-O-\beta$-D-glucupyranosyl-ester $\} \quad(1)$, and 13- $\{\beta$-D-6-deoxyglucopyranosyl-( $1 \rightarrow 2)-O$-[ $\beta$-D-glucopyranosyl-( $1 \rightarrow 3)$ - $\beta$-D-glucopyranosyl-oxy $\}$ ent-kaur-16-en-19-oic acid $\{\beta$-D-glucopyranosyl- $(1 \rightarrow 2)-$ $O$-[ $\beta$-D-glucopyranosyl- $(1 \rightarrow 3)-\beta$-D-glucopyranosyl-ester $\} \quad(2)$, on the basis of spectroscopic and chemical studies. The discovery of these two novel compounds is an important addition in expanding our understanding of the diversity of the diterpenoid glycosides present in the $S$. rebaudiana Bertoni. This is the first report of the isolation of the two novel diterpene glycosides 1-2 from $S$. rebaudiana Bertoni and their complete ${ }^{1} \mathrm{H}$ - and ${ }^{13} \mathrm{C}$-NMR spectral assignments that were made on the basis of spectral (COSY, HSQC, HMBC, and MS/MS) and chemical studies.

\section{Acknowledgments}

We wish to thank AMRI, Bothell Research Center, Bothell, WA for obtaining selected NMR spectral data.

\section{Conflicts of Interest}

The authors declare no conflict of interest.

\section{References}

1. Mosettig, E.; Nes, W.R. Stevioside. II. The structure of the aglucon. J. Org. Chem. 1955, 20, 884-899.

2. Mosettig, E.; Beglinger, U.; Dolder, F.; Lichiti, H.; Quitt, P.; Waters, J.A. The absolute configuration of steviol and isosteviol. J. Am. Chem. Soc. 1963, 85, 2305-2309.

3. Brandle, J.E.; Starrratt, A.N.; Gijen, M. Stevia rebaudiana: Its agricultural, biological and chemical properties. Can. J. Plant Sci. 1998, 78, 527-536.

4. Prakash, I.; Chaturvedula, V.S.P.; Markosyan, A. Isolation, characterization and sensory evaluation of a hexa $\beta$-D-glucopyranosyl diterpene from Stevia rebaudiana. Nat. Prod. Commun. 2013, in press.

5. Chaturvedula, V.S.P.; Prakash, I. A new diterpenoid glycoside from Stevia rebaudiana. Molecules 2011, 16, 2937-2943.

6. Chaturvedula, V.S.P.; Mani, U.; Prakash, I. Diterpene glycosides from Stevia rebaudiana. Molecules 2011, 16, 3552-3562.

7. Chaturvedula, V.S.P.; Prakash, I. Structures of the novel diterpene glycosides from Stevia rebaudiana. Carbohydr. Res. 2011, 346, 1057-1060.

8. Prakash, I.; Clos, J.F.; Chaturvedula, V.S.P. Stability of rebaudioside A under acidic conditions and its degradation products. Food Res. Int. 2012, 48, 65-75.

9. Prakash, I.; Campbell, M.; Miguel, R.I.S.; Chaturvedula, V.S.P. Synthesis and sensory evaluation of ent-kaurane diterpene glycosides. Molecules 2012, 17, 8908-8916.

10. Prakash, I.; Campbell, M.; Chaturvedula, V.S.P. Catalytic hydrogenation of the sweet principles of Stevia rebaudiana, rebaudioside B, rebaudioside C, and rebaudioside D and sensory evaluation of their reduced derivatives. Int. J. Mol. Sci. 2012, 13, 15126-15136. 
11. Chaturvedula, V.S.P.; Klucik, J.; Mani, U.; Prakash, I. Synthesis of ent-kaurane diterpene glycosides. Molecules 2011, 16, 8402-8409.

12. Bedir, E.; Toyang, N.J.; Khan, I.A.; Walker, L.A.; Clark, A.M. A new dammarane type triterpene glycoside from Polyscias fulva. J. Nat. Prod. 2001, 64, 95-97.

13. Chaturvedula, V.S.P.; Schilling, J.K.; Miller, J.S.; Andriantsiferana, R.; Rasamison, V.E.; Kingston, D.G.I. New cytotoxic oleanane saponis from the infructescences of Polyscias amplifolia from the Madagascar rainforest. Planta Med. 2003, 69, 440-444.

14. Huan, V.D.; Yamamura, S.; Ohtani, K.; Kasai, R.; Yamasaki, K.; Nham, N.T. Oleanane saponins from Polyscias fructicosa. Phytochemistry 1998, 47, 451-457.

15. Tanaka, T.; Nakashima, T.; Ueda, T.; Tomii, K.; Kouno, I. Facile discrimination of aldose enantiomers by reversed-phase HPLC. Chem. Pharm. Bull. 2007, 55, 899-901.

16. Ohtani, K.; Aikawa, Y.; Kasai, R.; Chou, W.; Yamasaki, K.; Tanaka, O. Minor diterpene glycosides from sweet leaves of Rubus suavissimus. Phytochemistry 1992, 31, 1553-1559.

17. Ohta, M.; Sasa, S.; Inoue, A.; Tamai, T.; Fujita, I.; Morita, K.; Matsuura, F. Characterization of novel steviol glycosides from leaves of Stevia rebaudiana Morita. J. Appl. Glycosci. 2010, 57, 199-209.

Sample Availability: Samples of the compounds 1-3 are available from the authors.

(C) 2013 by the authors; licensee MDPI, Basel, Switzerland. This article is an open access article distributed under the terms and conditions of the Creative Commons Attribution license (http://creativecommons.org/licenses/by/3.0/). 